\title{
INTERNAL DRAINAGE AND NITRATE LEACHING INA CORN-BLACK OAT-CORN SUCCESSION WITH TWO SPLIT NITROGEN APPLICATIONS
}

\author{
Flávia Carvalho Silva Fernandes ${ }^{1}$; Paulo Leonel Libardi2*; Laércio Alves de Carvalho ${ }^{3}$ \\ ${ }^{1}$ USP/ESALQ - Programa de Pós-Graduação em Física do Ambiente Agrícola. \\ ${ }_{3}^{2}$ USP/ESALQ - Depto. de Ciências Exatas, C.P. 09 - 13418-900 - Piracicaba, SP - Brasil. \\ ${ }^{3}$ UEMS/ Unidade de Cassilândia - Rod. MS $306 \mathrm{~km}$ 8, Zona Rural - 79540-000 - Cassilândia, MS - Brasil. \\ *Corresponding author <pllibard@esalq.usp.br>
}

\begin{abstract}
Excessive nitrate leaching represents a potential groundwater contamination. This study was carried out in an experiment area located in the city of Piracicaba/SP- Brazil, on a sandy-clayey loam soil. The objective was to evaluate internal drainage and nitrate leaching at the depth of $0.80 \mathrm{~m}$ in a crop succession, using ${ }^{15} \mathrm{~N}$-labeled ammonium sulfate, in two split $\mathrm{N}$ applications. Evaluations were based on two corn crops, the first grown during the 2003/2004 cropping season, and the second in the 2004/2005 season, and on a black oat crop grown during the off-season. Treatments consisted of a single $120 \mathrm{~kg} \mathrm{~N} \mathrm{ha}^{-1}$ rate, in the form of labeled $\left({ }^{15} \mathrm{~N}\right)$ ammonium sulfate, and two split $\mathrm{N}$ applications at 30-90 and 60-60 $\mathrm{kg} \mathrm{N} \mathrm{ha}^{-1}$. The fertilizer was applied in previously-defined subplots, in the first corn cultivation only (2003/04 cropping season). Evaluations included: soil physical and water content characterization; water flux density in the soil, and nitrate leaching at a $0.80 \mathrm{~m}$ depth; nitrogen in the soil solution derived from the fertilizer and ${ }^{15} \mathrm{~N}$ recovery by the soil solution at the end of the corn and black oat crop cycles. Loss by leaching in the $1^{\text {st }}$ corn cultivation was approximately 96 and $68 \mathrm{~kg} \mathrm{ha}^{-1}$ nitrate, for treatments with $60 \mathrm{~kg} \mathrm{ha}^{-1}$ and $30 \mathrm{~kg} \mathrm{~N} \mathrm{ha}^{-1}$ applied at seeding, respectively, of which only 3 and $1 \mathrm{~kg} \mathrm{ha}^{-1}$ were from the nitrogen fertilizer.

Key words: flux density, ${ }^{15} \mathrm{~N}$-ammonium sulfate, no-till, soil solution

\section{DRENAGEM INTERNA E LIXIVIAÇÃO DE NITRATO EM UMA SUCESSÃO MILHO-AVEIA-PRETA-MILHO, COM DOIS PARCELAMENTOS DE NITROGÊNIO}

\begin{abstract}
RESUMO: A lixiviação excessiva de nitrato pode ocasionar a contaminação de corpos d'água. O presente trabalho foi desenvolvido em área experimental no município de Piracicaba/SP - Brasil, em um solo de textura areno-argilosa. O experimento teve como objetivo avaliar a drenagem interna e a lixiviação de nitrato à profundidade de $0,80 \mathrm{~m}$ com o tempo em uma sucessão de culturas, utilizando-se sulfato de amônio marcado com ${ }^{15} \mathrm{~N}$, com dois parcelamentos de $\mathrm{N}$. As avaliações foram feitas em dois cultivos de milho, o primeiro no ano agrícola 2003/2004, o segundo em 2004/2005, e um de aveia-preta na entressafra. Os tratamentos consistiram de uma dose única de $120 \mathrm{~kg} \mathrm{ha}^{-1}$ de $\mathrm{N}$, na forma de sulfato de amônio marcado $\left({ }^{15} \mathrm{~N}\right)$ e os dois parcelamentos de $\mathrm{N}$ foram $30-90$ e $60-60 \mathrm{~kg} \mathrm{~N} \mathrm{ha}^{-1}$. O adubo foi aplicado em subparcelas, previamente definidas, apenas no primeiro cultivo do milho (safra 2003/04). Foram avaliados: caracterização físico-hídrica do solo; densidade de fluxo de água no solo e lixiviação de nitrato na profundidade de $0,80 \mathrm{~m}$; nitrogênio na solução do solo proveniente do fertilizante e recuperação de ${ }^{15} \mathrm{~N}$ pela solução do solo na profundidade de $0,80 \mathrm{~m}$ no final do ciclo das culturas de milho e aveia preta. A perda por lixiviação, a $0,80 \mathrm{~m}$ de profundidade, no $1^{\circ}$ cultivo de milho, foi de aproximadamente 96 e $68 \mathrm{~kg}$ $\mathrm{ha}^{-1}$ de nitrato, para os tratamentos com $60 \mathrm{~kg} \mathrm{ha}^{-1} \mathrm{e} 30 \mathrm{~kg} \mathrm{ha}^{-1} \mathrm{de} \mathrm{N}$ aplicado na semeadura, respectivamente, dos quais apenas 3 e $1 \mathrm{~kg} \mathrm{ha}^{-1}$ foram provenientes do fertilizante nitrogenado.

Palavras-chave: densidade de fluxo, ${ }^{15} \mathrm{~N}$-sulfato de amônio, plantio direto, solução do solo
\end{abstract}

\section{INTRODUCTION}

Leaching is the translocation of soluble salts that occurs via a descending flux of water in the soil profile (Kiehl, 1987). In the case of nitrogen, leaching is extremely important because it can noticeably de- crease the amount of ammonium and nitrate in the plough layer, and consequently reduce the availability of this nutrient. When excessive, leaching represents a potential groundwater contamination hazard by nitrates (Stark et al., 1983; Hoeft, 2003). Gava (2003) revised papers on $\mathrm{N}$ losses by leaching, between the 
years of 1978 and 1999, and observed that in 78\% of the experiments conducted in different soils and crops, fertilized on average with a rate of $92 \mathrm{~kg} \mathrm{~N} \mathrm{ha}^{-1}$, the total $\mathrm{N}$ losses by leaching were small, $1.26 \mathrm{~kg} \mathrm{~N}^{-1}$, on average. Nitrate losses by leaching were similar in the $1^{\text {st }}$ year of a corn crop, for three $\mathrm{N}$ rates applied $\left(22,100\right.$, and $\left.134 \mathrm{~kg} \mathrm{~N} \mathrm{ha}^{-1}\right)$, in two soil types (sandy and clayey), but in two other subsequent corn crops the rate of $134 \mathrm{~kg} \mathrm{~N} \mathrm{ha}^{-1}$ presented higher nitrate loss by leaching (Sogbedji et al., 2000). N losses by leaching can be controlled by splitting the application of nitrogen fertilizers, especially during high precipitation periods. In addition, maintaining the ground covered with plant material is important since plants constitute the only safe way of recycling nitrates. In studies on $\mathrm{N}$ fertilization (20 and $200 \mathrm{~kg} \mathrm{~N}$ $\mathrm{ha}^{-1}$ ) in corn with two types of management (harvested residues or returned residues) was verified that, during 30 years of simulation, nitrate losses by leaching were higher in plots where the residues were removed from the soil, when compared with plots where residues were returned to the soil (Gollany et al., 2005). However, did not find significant differences between cultivation systems or between split $\mathrm{N}$ applications, for the amount of nitrate found below $1.2 \mathrm{~m}$, during two years of experimentation (AlKaisi \& Licht, 2004). However, the amount of $\mathrm{N}$ lost by leaching varies significantly depending on the $\mathrm{N}$ rate, fertilizer application method, amount of rainfall, and soil properties (Kiehl, 1987).

Within this context, the objective of this paper was to evaluate internal drainage and nitrate leaching (total and derived from the fertilizer) at the depth of $0.80 \mathrm{~m}$ in a crop succession (corn-black oat-corn), using ${ }^{15} \mathrm{~N}$-labeled ammonium sulfate, in two split $\mathrm{N}$ applications.

\section{MATERIAL AND METHODS}

The field experiment was carried out in

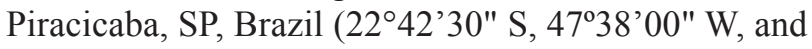
approximately $546 \mathrm{~m}$ elevation). According to Köppen's international classification, the climate is Cwa, known as "upland tropical". This is a mesothermal climate with a dry winter, with the mean temperature in the coolest month under $18^{\circ} \mathrm{C}$, reaching above $22^{\circ} \mathrm{C}$ in the hottest month. The annual means of temperature, precipitation, and relative humidity are $21.1^{\circ} \mathrm{C}, 1,257 \mathrm{~mm}$, and $74 \%$, respectively. The dry season occurs between the months of April and September, and July is the driest month. The rainiest month oscillates between January and February, and total precipitation in the driest month does not reach beyond $30 \mathrm{~mm}$.

The soil is a Typic Hapludox (Latossolo Vermelho Amarelo distrófico) (EMBRAPA, 1999). Before implementing the experiment, soil samples were collected at $0-0.20,0.20-0.40,0.40-0.60$, and $0.60-$ $0.80 \mathrm{~m}$ depths to determine the chemical and physical characteristics presented in Tables 1 and 2. The particle size analysis was performed according to methodology described in Gee \& Bauder (1986), bulk density by the volumetric ring method and particle density by the volumetric flask method described in Kiehl (1979). The project involved two corn crops, the first grown during the 2003/04 cropping season, and the second during the 2004/05 cropping season, in addition to a black oat crop grown during the off-season.

Before implementing the no-till system (NTS), in 2003, the soil was submitted to initial tillage (one subsoiling, one plowing, and two harrowings); in order to make the area more uniform, $50 \%$ dolomitic lime was applied before plowing and 50\% after plowing but before harrowing; the second harrowing was performed before seeding.

Liming was made at 0-0.2 m depth, in order to increase base saturation up to $60 \%$. The experimental design was organized as random blocks in a factorial arrangement, with four replicates. Treatments consisted of two split applications of a single dose of 120 $\mathrm{kg} \mathrm{N} \mathrm{ha}^{-1}$ : (i) $30 \mathrm{~kg} \mathrm{~N}^{-1}{ }^{-1}$ at seeding and $90 \mathrm{~kg} \mathrm{~N} \mathrm{ha}^{-1}$ as sidedressing at the 6-to-8-leaf stage, and (ii) $60 \mathrm{~kg}$ $\mathrm{N} \mathrm{ha}^{-1}$ at seeding and $60 \mathrm{~kg} \mathrm{~N} \mathrm{ha}^{-1}$ as sidedressing at the 6-to-8-leaf stage. The experimental plot consisted of 9 corn rows of $5.0 \mathrm{~m}$ long (an area of $36 \mathrm{~m}^{2}$, since the rows were space of $0.8 \mathrm{~m}$ ). The distance between plots was $2.0 \mathrm{~m}$. A subplot was demarcated in center of each plot for the application of ammonium sulfate

Table 1 - Soil chemical properties before installation of the experiment, at 0-0.20, 0.20-0.40, 0.40-0.60, and 0.60-0.80 m depth.

\begin{tabular}{|c|c|c|c|c|c|c|c|c|c|}
\hline Depth & $\mathrm{S}$ & $\begin{array}{c}\mathrm{pH} \\
\mathrm{CaCl}_{2}\end{array}$ & $\mathrm{OM}$ & P-resin & K & $\mathrm{Ca}$ & $\mathrm{Mg}$ & $\mathrm{H}+\mathrm{Al}$ & $\mathrm{Al}$ \\
\hline $\mathrm{m}$ & $\mathrm{mg} \mathrm{L}^{-1}$ & & $\mathrm{~g} \mathrm{dm}^{-3}$ & $\mathrm{mg} \mathrm{dm}{ }^{-3}$ & -...-- & - & $\mathrm{mmol}_{\mathrm{c}} \mathrm{dm}^{-3}-$ & - & - \\
\hline $0-0.2$ & 13.05 & 4.8 & 20 & 10 & 1.6 & 16 & 13 & 31 & 2.0 \\
\hline $0.2-0.4$ & 13.31 & 4.1 & 18 & 7 & 1.1 & 9 & 5 & 40 & 4.0 \\
\hline $0.4-0.6$ & 13.43 & 3.6 & 11 & 1 & 0.9 & 6 & 1 & 50 & 11.4 \\
\hline $0.6-0.8$ & 20.80 & 3.9 & 11 & 2 & 0.6 & 10 & 2 & 313 & 7.1 \\
\hline
\end{tabular}


Table 2 - Bulk density (Bd), density of particles (Dp), granulometric analysis, and soil textural class, before installation of the experiment, at 0-0.20, 0.20-0.40, 0.40-0.60, and 0.60-0.80 $\mathrm{m}$ depth.

\begin{tabular}{|c|c|c|c|c|c|}
\hline Depth & $\mathrm{Dp}$ & Sand & Silt & Clay & Textural Class \\
\hline $\mathrm{m}$ & $\mathrm{kg} \mathrm{dm}^{-3}$ & - - - & $\mathrm{g} \mathrm{kg}^{-1}$ & $\cdots$ & \\
\hline $0-0.20$ & 2.75 & 840 & 20 & 140 & Loamy sand \\
\hline $0.20-0.40$ & 2.76 & 800 & 20 & 180 & Sandy loam \\
\hline $0.40-0.60$ & 2.74 & 760 & 40 & 200 & Sandy-clay-loam \\
\hline $0.60-0.80$ & 2.69 & 760 & 40 & 200 & Sandy-clay-loam \\
\hline Depth & & $\mathrm{Bd}$ & Macro & Micro & Porosity \\
\hline $\mathrm{m}$ & & $\mathrm{kg} \mathrm{dm}^{-3}$ & - & $--\%_{0}^{--}$ & (n) \\
\hline $0-0.20$ & & 1.63 & 13 & 28 & 41 \\
\hline $0.20-0.40$ & & 1.68 & 13 & 26 & 39 \\
\hline $0.40-0.60$ & & 1.68 & 13 & 26 & 39 \\
\hline $0.60-0.80$ & & 1.64 & 13 & 27 & 39 \\
\hline
\end{tabular}

enriched with $5.5 \%$ of ${ }^{15} \mathrm{~N}$ atoms. This subplot consisted of the central $2.0 \mathrm{~m}$ of the three central rows of the plot. Ammonium sulfate not enriched with ${ }^{15} \mathrm{~N}$ was applied to the rest of the plot area as a source of N.

Furadan was applied on the sowing furrow (in order to control termites and caterpillars) at the rate of $20 \mathrm{~kg} \mathrm{ha}^{-1}$. During corn cultivation, a strict control of pests was also carried out, and the crop was sprayed with lufenuron (Match $300 \mathrm{~mL} \mathrm{ha}^{-1}$ ) against the fall armyworm (Spodoptera frugiperda J.E. Smith) whenever damage by the pest reached a rating of 1 (scraped leaves $-20 \%$ ). The postemergence herbicide glyphosate at the rate of $2.400 \mathrm{~g} \mathrm{ha}^{-1}$ a.i. was used to control weeds whenever needed. In order to control ants, an ant killer (a.i. deltamethrin) was sprayed at the recommended rate.

The corn cultivars used in the 2003/2004 and $2004 / 2005$ cropping seasons were the same, early cycle, normal-planting hybrids, used for grain production and highly resistant to lodging. This corn is very resistant to rusts (Puccinia sorghi, P. polyssora, and P. Physopella), Phaeosphaeria maydis, fusarium infections, stunting, and grain diseases. Sowing was performed manually on Dec.11, 2003 and Dec.1, 2004 for the $1^{\text {st }}$ and $2^{\text {nd }}$ cultivations, respectively. Seeds were distributed using a ruler, leaving two seeds at every $0.20 \mathrm{~m}$, thinned to one plant two weeks after emergence (Dec.18,2003 and Dec.8,2004), to obtain a final population of approximately 62.500 plants per hectare, i.e., 5 plants per meter of furrow. On Feb.24, 2004 and Feb.12, 2005, the corn plants reached full bloom and grains were harvested on Apr.14, 2004 and Apr.07, 2005.

After harvesting the corn crops (2003/2004 and 2004/2005 cropping seasons) the crop residues were cut with a chopper, simulating a drum roller chopper. The black oat was sown in rows, manually, on Sep.29, 2004, after the corn was harvested. In order to sow the oat, all corn trash was removed, and rows were spaced at $0.20 \mathrm{~m}$, using a seeding density of $60 \mathrm{~kg} \mathrm{ha}^{-1}$; the corn trash was later returned to the plot. The oat plants emerged on aug.09, 2004 and reached full bloom on oct.28, 2004. The crop was managed mechanically with a straw chopper, simulating a drum roller chopper.

A summary of the experimental procedures can be seen in Table 3 .

A base fertilization (phosphate and potassium) in the seeding furrow was applied for both corn cultivations at the rate of $90 \mathrm{~kg} \mathrm{P}_{2} \mathrm{O}_{5} \mathrm{ha}^{-1}$ and $50 \mathrm{~kg} \mathrm{~K}_{2} \mathrm{O}$ $\mathrm{ha}^{-1}$, in the form of single superphosphate and potassium chloride, respectively, and applied $5 \mathrm{~cm}$ alongside and below the seeds at seeding time, to avoid direct contact with the seeds. In black oat, the base fertilization consisted of $30 \mathrm{~kg} \mathrm{~N} \mathrm{ha}^{-1}, 90 \mathrm{~kg} \mathrm{P}_{2} \mathrm{O}_{5} \mathrm{ha}^{-1}$, and $50 \mathrm{~kg} \mathrm{~K}_{2} \mathrm{O} \mathrm{ha}^{-1}$ (Raij et al., 1997), in the form of ammonium sulfate, single superphosphate, and potassium chloride, respectively, performed by broadcasting after seeding. The nitrogen fertilizations used ammonium sulfate as source and were performed manually, in the seeding furrow (planting fertilization), incorporated into a shallow furrow at $0.20 \mathrm{~m}$ from the crop row (sidedressing), when the corn plants showed 6-8 completely unfolded leaves. The application of ammonium sulfate, enriched with ${ }^{15} \mathrm{~N}$, was done manually, only in the first corn cultivation, in the planting rows of the subplots (planting fertilization); at sidedressing, the fertilizer was manually incorporated to a furrow at $0.20 \mathrm{~m}$ from the seeding row.

The following assessments were carried out:

\section{Soil water flux}

One mercury manometer-tensiometer was installed on Dec.23, 2003 (5th day after emergence) in 
Table 3 - Experimental procedures.

\begin{tabular}{|c|c|}
\hline Date & Description \\
\hline December 24, 2003 & $\begin{array}{l}\text { Sowing of the } 1 \text { st cultivation ( } 2003 / 2004 \text { cropping season), base fertilization }\left(\mathrm{P}_{2} \mathrm{O}_{5}, \mathrm{~K}_{2} \mathrm{O}\right) \text { and }{ }^{15} \mathrm{~N} \\
\text { sulphate ammonium application. }\end{array}$ \\
\hline January 18,2004 & ${ }^{15} \mathrm{~N}$ enriched ammonium sidedressing application. \\
\hline April 14, 2004 & Corn harvest and chopper corn of residues crop. \\
\hline july 29, 2004 & Sowing of black oat (2004 cropping season) and base fertilization $\left(\mathrm{N}, \mathrm{P}_{2} \mathrm{O}_{5}, \mathrm{~K}_{2} \mathrm{O}\right)$. \\
\hline October 28,2004 & Chopper of black oat residues crop. \\
\hline December 1, 2004 & Sowing of the 2 nd cultivation (2004/2005 cropping season) and base fertilization $\left(\mathrm{N}_{2} \mathrm{P}_{2} \mathrm{O}_{5}, \mathrm{~K}_{2} \mathrm{O}\right)$. \\
\hline January 8,2005 & Nitrogen sidedressing application. \\
\hline April 7, 2005 & Corn harvest and chopper of corn residues crop. \\
\hline
\end{tabular}

the central row of each subplot involving ${ }^{15} \mathrm{~N}$, at the following depths: $0.70 ; 0.80$; and $0.90 \mathrm{~m}$. The tensiometer readings were made daily through the crop cycles. The tensiometers installed at the 0.70 and 0.90 $\mathrm{m}$ depths were used to determine total potential gradients $(\Delta \Phi t / \Delta Z)$, and the tensiometer at the $0.80 \mathrm{~m}$ depth was used to determine hydraulic conductivity $(\mathrm{K})$, at $\mathrm{Z}=0.80 \mathrm{~m}$. The product between daily $\mathrm{K}$ and $\Delta \Phi t / \Delta Z$ values resulted in the water flux density $\mathrm{q}\left(\mathrm{m}^{3} \mathrm{~m}^{-2} \mathrm{~s}^{-1}\right)$ at depth $Z=0.80 \mathrm{~m}$, according to eq. (1), or DarcyBuckingham equation (Libardi, 2005).

$$
q=-K \frac{\Delta \Phi_{t}}{\Delta Z}
$$

Total soil water potential for each depth was calculated by eq. (2);

$\Phi t=\Phi m+\Phi g$

where $\Phi_{\mathrm{g}}$ is gravitational potential, in $\mathrm{m}$ of water, measured considering a gravitational reference located at the soil surface.

The matric potential $\Phi_{\mathrm{m}}$, in $\mathrm{m}$ of water, was calculated according to eq. (3)

$\Phi m=12.6 H+h c+Z$

where: $\mathrm{H}=$ reading from the manometer, in $\mathrm{m} \mathrm{Hg} ; \mathrm{h}_{\mathrm{c}}$ $=$ height of the mercury reservoir in relation to the soil surface, in $\mathrm{m}$ of water; $\mathrm{Z}=$ installation depth of the tensiometers, in $\mathrm{m}$ of water.

Soil hydraulic conductivity as a function of matric potential was determined by the instantaneous profile methods (Libardi, 2005), following the procedure in Hillel et al. (1972). The function obtained was as follows (eq. 4)

$K=e^{70145 \Phi m-1.588}$

where $\mathrm{K}$ is expressed as $\mathrm{mm}$ day $^{-1}$ and $\Phi_{\mathrm{m}}$ as $\mathrm{m}$ water.

\section{Nitrate Leaching $\left(\mathrm{NO}_{3}{ }^{-}\right)$from the soil solution}

In the central row of subplots involving ${ }^{15} \mathrm{~N}$, together with the tensiometers, one soil solution extractor (Reichardt et al., 1977) was installed at the $0.80 \mathrm{~m}$ depth. The solution was removed by creating vacuum with a hand pump until the manometer indicated $430-480 \mathrm{kPa}$. The vacuum was maintained by closing the connection tube between the extractor and the vacuum pump and, after a minimum time of four hours (depending on soil water content), the solution was removed. Soil solution samples were collected on 03, 14, 27, and 29 January; 10, 15, 23, 24, and 27 February; 05 March; 21 April; 27 May; 04 June; 17 and 27 October; 30 November, and 27 December 2004; and on 09 and 30 January; 05 and 27 February; 25 March, and 06 and 21 April/05. After collection, the samples were frozen and later analyzed in a FIA system - Flow Injection Analysis, according to procedures described in Gine et al. (1980). Thus, the nitrate concentrations ( $\mathrm{C}_{\mathrm{NO}_{3}^{-}}$) in the soil solution were determined as $\mathrm{mg} \mathrm{L}^{-1}$. The $\mathrm{NO}_{3}^{-}$flux (leaching) at depth $\mathrm{Z}=0.80$ $\mathrm{m}$ was determined by the product between water flux density (q) and $\mathrm{NO}_{3}^{-}$concentration $\left(\mathrm{kg} \mathrm{L}^{-1}\right.$ solution) in the soil solution extracted with the extractor, i.e.,

$q_{\mathrm{NO}_{3}^{-}}=q \mathrm{C}_{\mathrm{NO}_{3}^{-}}$,

where: $q_{\mathrm{NO}_{3}^{-}}\left(\mathrm{kg} \mathrm{m}^{-2} \mathrm{~s}^{-1}\right)=$ soil nitrate flux density at the $0.80 \mathrm{~m}$ depth at a given instant; $C_{\mathrm{NO}_{3}^{-}}\left(\mathrm{kg} \mathrm{m}^{-3}\right)=$ mean $\mathrm{NO}_{3}^{-}$concentration in the soil solution at the same instant and depth.

In order to determine $\mathrm{N}^{-\mathrm{NO}_{3}}{ }_{3}^{-}$from the fertilizer in the soil solution (NSSDF), the samples were distilled in a micro-Kjeldahl system, by alkalinizing the solution with $\mathrm{MgO}$, and the distillate was collected in $\mathrm{a}_{3} \mathrm{BO}_{3}$ solution $\left(20 \mathrm{~g} \mathrm{~L}^{-1}\right)$, and later titrated with $\mathrm{H}_{2} \mathrm{SO}_{4} 0.05 \mathrm{~mol} \mathrm{~L}^{-1}$. The ${ }^{15} \mathrm{~N}$ determinations in samples distilled from the soil solution were performed in a magnetic-sector mass spectrom- 
eter with electron impact ionization - IRMS - ATLAS MAT $\mathrm{CH}_{4}$ (Trivelin et al., 1973). The concentrations of nitrate derived from the fertilizer $\left(\mathrm{C}_{\mathrm{nf}}\right)$ were determined based on the results obtained, according to eq. (6),

$$
C_{n f}=\frac{\% N S S D F}{100} x C_{\mathrm{NO}_{3}^{-}}
$$

where: \%NSSDF is the $\mathrm{NO}_{3}^{-}$percentage in the soil solution derived from the fertilizer. ${ }^{1}$

The data were submitted to analysis of variance and the means were compared by Tukey test $P=0.05$ (SANEST program).

\section{RESULTS AND DISCUSSION}

\section{Soil water flux density in corn $(2003 / 2004$ and 2004/2005 cropping seasons) and black oat (2004 cropping season)}

In both corn cultivations, total rainfall was 615 and $656 \mathrm{~mm}$, respectively (Figures 1 and 2), higher than the minimum indicated for the crop to produce good yields, without the need to use irrigation (Fancelli \& Dourado Neto, 2005).

Although a precipitation increase of $41 \mathrm{~mm}$ occurred in the $2^{\text {nd }}$ corn cultivation in relation to the $1^{\text {st }}$ (Figure 2), this did not imply greater crop development. In the $1^{\text {st }}$ corn cultivation (Figure 1) $(2003 / 2004$ cropping season), emergence, sidedressing fertilization, and flowering occurred under better soil moisture conditions, resulting from frequent precipitations in the period. On the other hand, male flowering in the corn cultivation in the following year (2004/2005 cropping season) occurred under widely unfavorable conditions. In this crop, flowering is a period considered critical

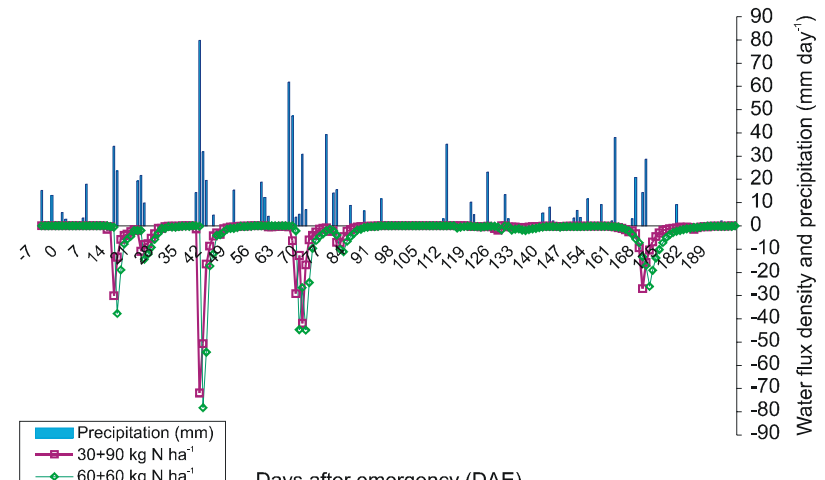

Figure 1 - Water flux density (mean of four replications) and precipitation as a function of time (DAE) in corn, 2003/2004 cropping season. Negative number of DAE refer to period before emergency. for grain productivity, being strongly affected by drought conditions (Magalhães et al., 1995; Caramori et al., 1999).

Water deficit periods of one week at flowering may cause a yield reduction around 50\% (Fancelli \& Dourado Neto, 2005). Because of precipitation, high water flux densities were obtained in both corn cultivations, reaching means (for treatments studied) of 4.10 and $3.68 \mathrm{~mm}^{-1 a y}{ }^{-1}$, maximum values of 74.5 and $53.3 \mathrm{~mm} \mathrm{day}^{-1}$, and totals of 479 and $455 \mathrm{~mm}$ for the $1^{\text {st }}$ and $2^{\text {nd }}$ cycles, respectively. Therefore, this fact may have favored high nitrate leaching rates. Flux density values of $188 \mathrm{~mm}$ for corn grown under no-till, and $38 \mathrm{~mm}$ under conventional planting; these values were well below the data found in study observed by Gava (2003). Higher water flux densities, in corn grown in lysimeters under the no-till and conventional systems, in a period of 2 consecutive years (Shipitalo \& Edwards, 1993). These authors found mean values from 645 to $464 \mathrm{~mm}$ (87/88 cropping season) and from 799 to $596 \mathrm{~mm}(88 / 89)$ for the no-till and conventional systems, respectively. In turn, with in a sandy clay loam soil under different management conditions and found results close to this experiment were found by Castro et al. (2002). According to the authors, the highest flux densities found were $40 \mathrm{~mm}$ day $^{-1}$ in a soil under pasture and conventional cultivation, $25 \mathrm{~mm}^{-1 a y}{ }^{-1}$ under no-till, and $180 \mathrm{~mm} \mathrm{day}^{-1}$ in a bare soil. The explanation for the obtained high flux densities could be the texture of the studied soil, classified as sandy, because, in general, these soils have smaller water and nutrients retention capacities and high susceptibility to erosion than clayey soils (Lima \& Lima, 2000).

In the black oat cycle, during the 2004 cropping season (Figure 3), a total precipitation of 146.5

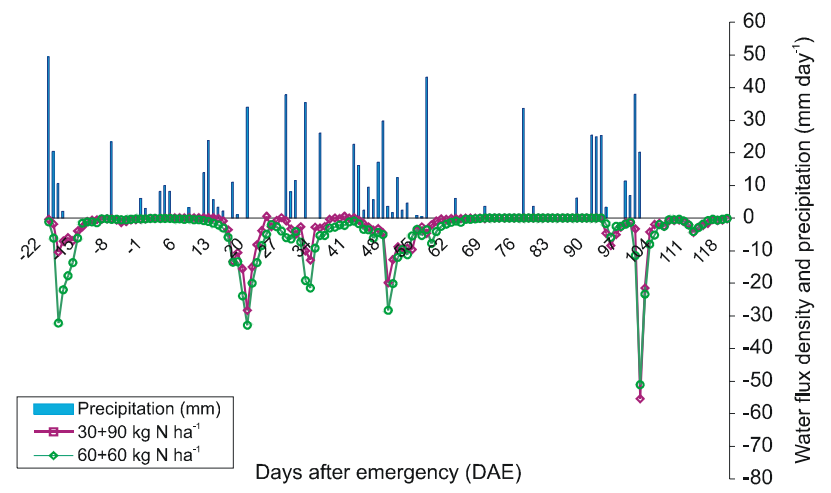

Figure 2 - Water flux density (mean of four replications) and precipitation as a function of time (DAE) in corn, 2004/2005 cropping season. Negative numbers of DAE refer to period before emergency.

\footnotetext{
${ }^{1}$ Note: Because ATLAS MAT $\mathrm{CH}_{4}$ only detects ${ }^{15} \mathrm{~N}$ in samples that contain at least $0.5 \mathrm{mg} \mathrm{N}$ total , percentages in ${ }^{15} \mathrm{~N}$ atoms were detected only on 09, 14, and 29 January; 27 February, 21 April, and 27 October/04; and on 30 January and 21 April/05. The analyses were carried out at CENA/USP's Stable Isotopes Laboratory.
} 
$\mathrm{mm}$ can be observed, irregularly distributed, and $68 \%$ of the total occurred between 54 and 66 Days after emergency (DAE), while the remaining 32\% occurred near the flowering season (80 DAE). Consequently, the water flux densities were higher in that period, reaching maximum values of 4 and $21 \mathrm{~mm} \mathrm{day}^{-1}$ and total values in the crop cycle of 21.7 and 73.6, respectively, for the 30-90 and 60-60 $\mathrm{kg} \mathrm{N} \mathrm{ha}^{-1}$ treatments. The irregular rainfall distribution during the black oat cycle could have been responsible for the small amount of black oat dry matter mass obtained, which varied from 2,865 to $3,158 \mathrm{~kg} \mathrm{ha}^{-1}$.

With respect to differences between treatments, a small flux density variation occurred between treatments $30-90$ and $60-60 \mathrm{~kg} \mathrm{~N}^{-1}$ in both corn cultivations and in the black oat cultivation. However, the same behavior was verified, i.e., higher flux densities

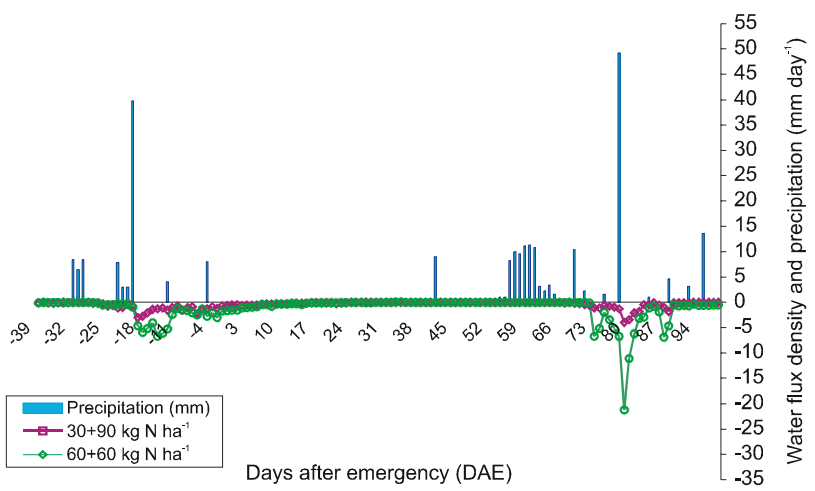

Figure 3 - Water flux density (mean of four replications) and precipitation as a function of time (DAE) in black oat, 2004 cropping season. Negative numbers of DAE refer to period before emergency. were observed right after intense precipitations. In the three cultivations, the treatment where $60 \mathrm{~kg} \mathrm{~N} \mathrm{ha}^{-1}$ were applied at seeding and $60 \mathrm{~kg} \mathrm{~N} \mathrm{ha}^{-1}$ as sidedressing showed higher water flux densities during the entire cycle. This could probably be due to greater root development in that treatment, which interfered with the quantity of macropores, because of the exploitation of a larger soil volume: according to Martins et al. (2002), the roots increase the degree of soil structuring by releasing exudates, and increase $\mathrm{OM}$ contents via biochemical cycling (formation, death, and decay of fine roots) contributing to stabilize aggregates, increasing soil macroporosity. Thus, Rasse \& Smucker (1999) demonstrated that an increased number of macropores resulted in higher drainage flow. The water flux densities for the 30-90 and $60-60 \mathrm{~kg} \mathrm{~N}^{-1}$ treatments during the $2^{\text {nd }}$ cultivation (Figure 2 ) were smaller than in the $1^{\text {st }}$ cycle (Figure 1), although precipitation was higher during this period. This fact can probably be explained by the formation of trash, which, in turn, influenced water retention at the surface, in agreement with data obtained by Carvalho et al. (1999) and Castro et al. (2002), but disagreeing from Gava (2003). Another explanation for this fact could also be the better precipitation distribution in the $2^{\text {nd }}$.

\section{Leaching of total nitrate and of nitrate derived from ammonium sulfate $\left({ }^{15} \mathrm{~N}\right)$}

In the $1^{\text {st }}$ corn cycle (2003/2004 cropping season), it can be verified in the Table 4 that the highest nitrate fluxes, in both treatments, were between 30 60 and 60-90 days after plant emergence (DAE); the highest water drainage values at $0.80 \mathrm{~m}$ were also ob-

Table 4 - Water drainage and leaching of total nitrate and of fertilizer-derived nitrate (DF) at $0.80 \mathrm{~m}$ depth in corn, 2003/2004 cropping season. $\mathrm{DAE}=$ Days after emergency

\begin{tabular}{|c|c|c|c|c|c|}
\hline \multirow{3}{*}{ Treatment } & \multirow{3}{*}{ DAE } & \multicolumn{4}{|c|}{ Corn cultivation - 2003/2004 cropping season } \\
\hline & & \multirow{2}{*}{ Precipitation } & \multirow{2}{*}{ Water drainage at $0.80 \mathrm{~m}$} & \multicolumn{2}{|c|}{$\mathrm{NO}_{3}^{-}$leaching } \\
\hline & & & & total & Fertilizer (DF) \\
\hline $\mathrm{Kg} \mathrm{N} \mathrm{ha}^{-1}$ & & $-1-1-1-10$ & mm - mo & $-1-1-1-10$ & 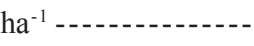 \\
\hline 3090 & $0-30$ & 110.1 & $103.62 \mathrm{a}$ & $10.27 \mathrm{a}$ & $0.20 \mathrm{a}$ \\
\hline 6060 & & & $129.91 \mathrm{a}$ & $13.97 \mathrm{a}$ & $0.18 \mathrm{a}$ \\
\hline 3090 & $30-60$ & 200.6 & $165.67 \mathrm{a}$ & $33.14 \mathrm{a}$ & $1.79 \mathrm{a}$ \\
\hline 6060 & & & $180.11 \mathrm{a}$ & $20.00 \mathrm{~b}$ & $0.28 \mathrm{~b}$ \\
\hline 3090 & $60-90$ & 239.4 & $155.71 \mathrm{~b}$ & $24.93 \mathrm{~b}$ & $0.94 \mathrm{a}$ \\
\hline 6060 & & & $218.63 \mathrm{a}$ & $61.64 \mathrm{a}$ & $0.86 \mathrm{a}$ \\
\hline 3090 & $90-120$ & 615.0 & $1.54 \mathrm{~b}$ & $0.01 \mathrm{a}$ & $0.07 \mathrm{a}$ \\
\hline 6060 & & & $3.65 \mathrm{a}$ & $0.01 \mathrm{a}$ & $0.07 \mathrm{a}$ \\
\hline 3090 & Total & 615.0 & $426.54 \mathrm{~b}$ & $68.35 \mathrm{~b}$ & $3.00 \mathrm{a}(4.15 \%)$ \\
\hline 6060 & & & $532.29 \mathrm{a}$ & $95.61 \mathrm{a}$ & $1.39 \mathrm{~b}(2.16 \%)$ \\
\hline
\end{tabular}

Note: Treatments 30-90 and/or 60-60 refer to the application of $\mathrm{N}$ at seeding and at the 6-8-leaf stage. DAE stands for days after emergence. Means followed by common letters, in the column, are not different at the $5 \%$ significance level by Tukey test. 
served during this period. In the period between 30$60 \mathrm{DAE}$, the treatment where $30 \mathrm{~kg} \mathrm{~N} \mathrm{ha}^{-1}$ were applied at seeding showed greater nitrate leaching (33.14 $\mathrm{kg} \mathrm{ha}^{-1}$ ), significantly differing from the treatment where $60 \mathrm{~kg} \mathrm{~N} \mathrm{ha}^{-1}$ were applied at seeding, even though drainage was smaller in this treatment. This result can be explained by the higher amount of $\mathrm{N}$ applied as sidedressing in the $30-90 \mathrm{~kg} \mathrm{~N}^{-1}$ treatment, which was performed at $22 \mathrm{DAE}$; however, high precipitation $(150.2 \mathrm{~mm})$ was recorded in the subsequent period ( 37 to $42 \mathrm{DAE}$ ), which provided higher water drainage during that period. This fact can be demonstrated by the higher amount of nitrate in the soil solution derived from the fertilizer ( $1.79 \mathrm{~kg} \mathrm{ha}^{-1}$ nitrate) in the $30-90 \mathrm{~kg} \mathrm{~N}^{-1}$ treatment, when compared with the $60-60 \mathrm{~kg} \mathrm{~N}^{-1}$ treatment $\left(0.28 \mathrm{~kg} \mathrm{ha}^{-1}\right.$ nitrate). Between 60-90 DAE, however, flux density in treatment 60-60 (61.64 $\mathrm{kg} \mathrm{ha}^{-1}$ nitrate) was higher, differing significantly from treatment $30-90 \mathrm{~kg} \mathrm{~N} \mathrm{ha}^{-1}$. Greater drainage was also verified in the treatment where $60 \mathrm{~kg} \mathrm{~N} \mathrm{ha}^{-1}$ were applied at seeding, probably because of greater plant root development, which might have increased the number of macropores, allowing drainage to increase, as discussed in the previous topic.

The treatments were not different for water drainage at $0.80 \mathrm{~m}$ until $60 \mathrm{DAE}$, and no differences occurred between treatments for nitrate leaching until $30 \mathrm{DAE}$ and in the period from 90-120 DAE. In the later period, however, the quantity of nitrate leached was practically null, since drainage was practically negligible as a consequence of low precipitation.

Therefore, during the $1^{\text {st }}$ corn cycle, 68.35 and $95.61 \mathrm{~kg} \mathrm{ha}^{-1}$ nitrate (or 14.43 and $21.59 \mathrm{~kg} \mathrm{~N}$ $\mathrm{ha}^{-1}$ ), for treatments $30-90$ and $60-60 \mathrm{~kg} \mathrm{~N} \mathrm{ha}^{-1}$, respectively, were leached at $0.80 \mathrm{~m}$, of which 3.0 and $1.39 \mathrm{~kg} \mathrm{ha}^{-1}$ were derived from the fertilizer applied $\left(120 \mathrm{~kg} \mathrm{~N} \mathrm{ha}^{-1}\right)$. These values, notably in the $2^{\text {nd }}$ corn cultivation, can be considered high when compared with results observed in the literature. Before the experiment was implemented, this soil probably already had a high amount of native $\mathrm{N}$, derived from previous crops. Libardi \& Reichardt (1978) were pioneers on this subject and verified losses of $6.7 \mathrm{~kg} \mathrm{~N} \mathrm{ha}^{-1}$ during a one-year period at a depth of $1.2 \mathrm{~m}$, when a rate of $120 \mathrm{~kg} \mathrm{~N} \mathrm{ha}^{-1}$ was applied to a bean crop. Again in bean, Meirelles et al. (1980) found a leaching value of $15 \mathrm{~kg} \mathrm{~N} \mathrm{ha}^{-1}$ at a $1.20 \mathrm{~m}$ depth during one year of experimentation, and only $1.34 \mathrm{~kg} \mathrm{~N} \mathrm{ha}^{-1}$ came from the applied fertilizer $\left(100 \mathrm{~kg} \mathrm{~N} \mathrm{ha}^{-1}\right)$. In a corn experiment under no-till, Gava (2003) obtained very low N leaching values in a clayey-textured soil. This author found a maximum $\mathrm{N}$ flux density value of $1,500 \mathrm{~g} \mathrm{ha}^{-1}$, at $0.50 \mathrm{~m}$, in the period from 20 to $128 \mathrm{DAE}$, when
$25 \mathrm{~kg} \mathrm{~N} \mathrm{ha}^{-1}$ were applied at seeding and $50 \mathrm{~kg} \mathrm{~N}^{-1}$ were applied as sidedressing. In turn, Gollany et al. (2005) studied $\mathrm{N}$ rates in clayey soils and found mean leached nitrate values of 32 and $78 \mathrm{~kg} \mathrm{ha}^{-1}$ year $^{-1}$, when applying rates of 20 and $200 \mathrm{~kg} \mathrm{~N} \mathrm{ha}^{-1}$ in corn.

In addition to high precipitation values during the crop cycle $(615.0 \mathrm{~mm})$, another factor that may have had an influence at relatively high nitrate flux densities at $0.80 \mathrm{~m}$ was soil type (sandy), in agreement with Sogbedji et al. (2000), who stated that nitrate leaching was higher in sandy soils than in clayey soils. However, high leaching can be due to both intense precipitations and reduced soil volume explored by the roots (Silva, 1982 and Camargo et al., 1999).

However, it is noteworthy that although greater nitrate leaching (Table 4) was detected in treatment 60-60 during the $1^{\text {st }}$ corn cycle, treatment $30-90 \mathrm{~kg} \mathrm{~N} \mathrm{ha}^{-1}$ showed a higher fertilizer-derived nitrogen value, which indicates that in treatment 60$60 \mathrm{~kg} \mathrm{~N} \mathrm{ha}{ }^{-1}$, most leached nitrate came from the soil. Therefore, it can be supposed that plants in the treatment where $60 \mathrm{~kg} \mathrm{~N}^{-1}$ were applied at seeding and $60 \mathrm{~kg} \mathrm{ha}^{-1}$ were applied as sidedressing, absorbed more fertilizer-derived $\mathrm{N}$. These results indicate that higher $\mathrm{N}$ sidedressing rates provide higher losses of $\mathrm{N}$ derived from the fertilizer, in agreement with Sainz Rozas et al. (2004), who obtained increased nitrate leaching when the $\mathrm{N}$ dose applied at the $\mathrm{V}_{6}$ stage of corn was increased. Nitrogen losses of $66.5 \mathrm{~kg} \mathrm{ha}^{-1}$ by leaching when $200 \mathrm{~kg} \mathrm{~N} \mathrm{ha}^{-1}$ were applied at corn planting (Costa et al., 2003).

Table 5 presents water flux density and nitrate leaching (total and fertilizer-derived) values corresponding to the fallow period between the $1^{\text {st }}$ corn cultivation and black oat cultivation, between black oat and the $2^{\text {nd }}$ corn cultivation, and during black oat cultivation. In both fallow periods, water drainage was higher in treatment 60-60. However, nitrate leaching values showed different between treatments only in the period between the $1^{\text {st }}$ cultivation and the black oat crop. In the period between the black oat crop and the $2^{\text {nd }}$ corn cultivation, nitrate leaching was approximately 0.07 and $0.03 \mathrm{~kg} \mathrm{ha}^{-1}$ in the 30-90 and 60-60 $\mathrm{kg} \mathrm{N} \mathrm{ha}{ }^{-1}$ treatments, respectively. No precipitation occurred in the period from 0-40 DAE during the black oat cycle, in the 2004 cropping season (Table 5), which caused low water drainage values at $0.80 \mathrm{~m}$ depth, and no nitrogen loss by leaching in that period. During the black oat cultivation period (0-80 DAE), total water drainage was 21.7 and $73.57 \mathrm{~mm}$, and the soil solution removed gave leached nitrate results of 0.62 and $2.64 \mathrm{~kg} \mathrm{ha}^{-1}$ for treatments $30-90$ and $60-60 \mathrm{~kg} \mathrm{~N} \mathrm{ha}^{-1}$, respectively. Of these, 0.01 and $0.02 \mathrm{~kg} \mathrm{~N} \mathrm{ha}^{-1}$ came from the fertilizer. 
Most of these values were obtained in the period from 40-80 DAE, as a consequence of precipitations occurring only at the end of the black oat cycle.

In the $2^{\text {nd }}$ corn cultivation, during the 2004/ 2005 cropping season (Table 6), water drainage values at 0.80 depth showed the same behavior when compared with the $1^{\text {st }}$ corn cycle (Table 4 ), for all periods studied, i.e., treatment 60-60 resulted in higher drainage values.

The lowest drainage values were obtained in the period from 60-90 DAE (flowering season), due to reduced precipitation, while in the $1^{\text {st }}$ corn cultivation the rainfall shortage period occurred between 90-120 DAE (end of cycle). In the final accounting for the crop cycle (2004/2005 cropping season), water drainage values at $0.80 \mathrm{~m}(379.64$ and $530.90 \mathrm{~mm}$ ) for treatments 30-90 and $60-60 \mathrm{~kg} \mathrm{~N} \mathrm{ha}^{-1}$, respectively, were not higher than those verified in the $1^{\text {st }}$ corn cultivation, despite the fact that higher precipitation occurred.

With regard to nitrate leaching, in all periods for this crop, except at 60-90 DAE, results proved higher in the 60-60 treatment, being significantly different from the $30-90 \mathrm{~kg} \mathrm{~N} \mathrm{ha}^{-1}$ treatment only in the period from 90-120 DAE.
Total leached nitrate values $(23.02$ and $28.37 \mathrm{~kg}$ $\mathrm{ha}^{-1}$ ) were not different between treatments; however, results were lower when compared with those in the $1^{\text {st }}$ cultivation. This may have occurred due to the accumulation of plant residues on the soil surface as soon as the end of the $1^{\text {st }}$ year of implementation of the notill system. Halvorson et al. (2001) using wheat, and Sainju \& Singh (2001) with corn, concluded that below a depth of $1.50 \mathrm{~m}$, the conventional system accumulated more nitrate than the no-till system. Weed \& Kanwar (1996) reported that nitrate loss in a system using no-till was $74 \mathrm{~kg} \mathrm{ha}^{-1}$ smaller than under conventional planting, disagreeing from Gava (2003), who found greater nitrogen losses by leaching in no-till corn (mean of approximately $1,177 \mathrm{~g} \mathrm{ha}^{-1}$ ) when this system was compared with conventional planting $\left(226 \mathrm{~g} \mathrm{ha}^{-1}\right)$.

With regard to the residual effect of the fertilizer (Table 6) at a depth of $0.80 \mathrm{~m}$, the results of nitrate derived from the fertilizer were identical for the $30-90$ and $60-60 \mathrm{~kg} \mathrm{~N}^{-1}{ }^{-1}$ treatments $\left(0.13 \mathrm{~kg} \mathrm{ha}^{-1} \mathrm{ni}-\right.$ trate). The amount of leached nitrate derived from the fertilizer (residual effect of $120 \mathrm{~kg} \mathrm{~N} \mathrm{ha}^{-1}$ ), applied in the $1^{\text {st }}$ corn cultivation was very low after the succession of crops studied (corn-black oat-corn).

Table 5 - Water drainage and leaching of total nitrate and of fertilizer-derived nitrate (DF) at $0.80 \mathrm{~m}$ depth in the off-seasons and in the black oat crop (2004 cropping season). DAE = Days after emergency

\begin{tabular}{|c|c|c|c|c|c|}
\hline \multirow{3}{*}{ Treatment } & & \multicolumn{4}{|c|}{ Between the 1 st corn cultivation and black oat } \\
\hline & & \multirow{2}{*}{ Precipitation } & \multirow{2}{*}{ Water drainage at $0.80 \mathrm{~m}$} & \multicolumn{2}{|c|}{$\mathrm{NO}_{3}^{-}$leaching } \\
\hline & & & & total & Fertilizer (DF) \\
\hline $\mathrm{Kg} \mathrm{N} \mathrm{ha}^{-1}$ & & \multicolumn{2}{|c|}{ - } & \multicolumn{2}{|c|}{ - } \\
\hline 3090 & Total & 296.0 & $151.18 \mathrm{~b}$ & $2.81 \mathrm{~b}$ & - \\
\hline \multirow[t]{2}{*}{6060} & & & $243.24 \mathrm{a}$ & $4.77 \mathrm{a}$ & - \\
\hline & & \multicolumn{4}{|c|}{ Black oat - 2004 cropping season } \\
\hline \multirow[t]{2}{*}{ Treatment } & DAE & Precipitation & Water drainage at $0.80 \mathrm{~m}$ & \multicolumn{2}{|c|}{$\mathrm{NO}_{3}^{-}$leaching } \\
\hline & & & & total & Fertilizer (DF) \\
\hline $\mathrm{Kg} \mathrm{N} \mathrm{ha}^{-1}$ & & \multicolumn{2}{|c|}{ - } & \multicolumn{2}{|c|}{ - } \\
\hline 3090 & $0-40$ & 0.0 & $6.68 \mathrm{~b}$ & $0.00 \mathrm{a}$ & - \\
\hline 6060 & & & $11.88 \mathrm{a}$ & $0.00 \mathrm{a}$ & - \\
\hline 3090 & $40-80$ & 146.5 & $15.02 \mathrm{~b}$ & $0.62 \mathrm{~b}$ & $0.01 \mathrm{a}$ \\
\hline 6060 & & & $61.69 \mathrm{a}$ & $2.64 \mathrm{a}$ & $0.02 \mathrm{a}$ \\
\hline 3090 & Total & 146.5 & $21.70 \mathrm{~b}$ & $0.62 \mathrm{~b}$ & 0.01 a $(0.02 \%)$ \\
\hline \multirow[t]{2}{*}{6060} & & & $73.57 \mathrm{a}$ & $2.64 \mathrm{a}$ & 0.02 a $(0.03 \%)$ \\
\hline & & \multicolumn{4}{|c|}{ Between black oat and the 2 nd corn cultivation } \\
\hline \multirow[t]{2}{*}{ Treatment } & & Precipitation & Water drainage at $0.80 \mathrm{~m}$ & \multicolumn{2}{|c|}{$\mathrm{NO}_{3}^{-}$leaching } \\
\hline & & & & total & Fertilizer (DF) \\
\hline $\mathrm{Kg} \mathrm{N} \mathrm{ha}^{-1}$ & & - & - mm - & 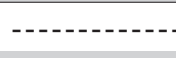 & $h^{-1}-\ldots \ldots$ \\
\hline 3090 & Total & 136.3 & $56.78 \mathrm{~b}$ & $0.07 \mathrm{a}$ & - \\
\hline 6060 & & & $142.14 \mathrm{a}$ & $0.03 \mathrm{a}$ & - \\
\hline
\end{tabular}

Note: Treatments 30-90 and/or 60-60 refer to the application of $\mathrm{N}$ at seeding and at the 6-8-leaf stage. DAE stands for days after emergence. Means followed by common letters, in the column, are not different at the $5 \%$ significance level by Tukey test. 
Table 6 - Water drainage and leaching of total nitrate and of fertilizer-derived nitrate (DF) at $0.80 \mathrm{~m}$ depth in corn, 2004/2005 cropping season. DAE $=$ Days after emergency

\begin{tabular}{|c|c|c|c|c|c|}
\hline \multirow{3}{*}{ Treatment } & \multirow{3}{*}{ DAE } & \multicolumn{4}{|c|}{ Corn cultivation - 2004/2005 cropping season } \\
\hline & & \multirow{2}{*}{ Precipitation } & \multirow{2}{*}{ Water drainage at $0.80 \mathrm{~m}$} & \multicolumn{2}{|c|}{$\mathrm{NO}_{3}^{-}$leaching } \\
\hline & & & & total & Fertilizer (DF) \\
\hline $\mathrm{Kg} \mathrm{N} \mathrm{ha}^{-1}$ & & $-\cdots-\cdots-1$ & 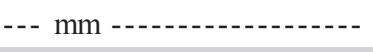 & 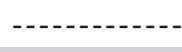 & $h^{-1}-\ldots-\cdots-1$ \\
\hline 3090 & $0-30$ & 181.9 & $113.16 \mathrm{~b}$ & $4.80 \mathrm{a}$ & - \\
\hline 6060 & & & $180.17 \mathrm{a}$ & $6.45 \mathrm{a}$ & - \\
\hline 3090 & $30-60$ & 231.7 & $132.50 \mathrm{~b}$ & $11.79 \mathrm{a}$ & - \\
\hline 6060 & & & $211.40 \mathrm{a}$ & $9.80 \mathrm{a}$ & - \\
\hline 3090 & $60-90$ & 78.4 & $0.61 \mathrm{~b}$ & $0.00 \mathrm{a}$ & - \\
\hline 6060 & & & $4.74 \mathrm{a}$ & $0.00 \mathrm{a}$ & - \\
\hline 3090 & $90-120$ & 164.4 & $133.37 \mathrm{a}$ & $6.43 \mathrm{~b}$ & $0.13 \mathrm{a}$ \\
\hline 6060 & & & $134.59 \mathrm{a}$ & $12.12 \mathrm{a}$ & $0.13 \mathrm{a}$ \\
\hline 3090 & Total & 656.4 & $379.64 \mathrm{~b}$ & $23.02 \mathrm{a}$ & 0.13 a $(0.25 \%)$ \\
\hline 6060 & & & $530.90 \mathrm{a}$ & $28.37 \mathrm{a}$ & 0.13 a $(0.21 \%)$ \\
\hline
\end{tabular}

Note: Treatments 30-90 and/or 60-60 refer to the application of $\mathrm{N}$ at seeding and at the 6-8-leaf stage. DAE stands for days after emergence. Means followed by common letters, in the column, are not different at the 5\% significance level by Tukey test.

\section{CONCLUSIONS}

Split $\mathrm{N}$ applications influenced water drainage and total nitrate leaching at the soil depth of $0.8 \mathrm{~m}$; these were always higher in the treatment that received the highest rate at seeding;

Nitrate leaching derived from the fertilizer was very low: $3.0 \mathrm{~kg} \mathrm{ha}^{-1}$ in the treatment with the smallest rate and $1.4 \mathrm{~kg} \mathrm{ha}^{-1}$ in the treatment with the highest rate at seeding.

\section{REFERENCES}

AL-KAISI, M.; LICHT, M.A. Effect of strip on corn nitrogen uptake and residual soil nitrate accumulation compared with no-tillage and chisel plow. Agronomy Journal, v.96, p.11641171, 2004.

CAMARGO, F.A.O.; GIANELLO, C.; TEDESCO, M.J.; VIDOR, C. Nitrogênio orgânico do solo. In: SANTOS, G.A.; CAMARGO, F.A.O. (Ed.). Fundamentos da matéria orgânica do solo: ecossistemas tropicais e subtropicais. Porto Alegre: Gênesis, 1999. cap.7, p.117-133.

CARAMORI, P.H.; WREGE, M.S.; GONÇALVES, S.L. Zoneamento da cultura do milho "safrinha" e épocas de semeadura no Estado do Paraná. In: SEMINÁRIO SOBRE A CULTURA DO MILHO "SAFRINHA", 5., Barretos. Anais. Barretos: CATI/IAC/IEA, 1999. p.15-19.

CARVALHO, M.A.C.; LAZARINI, E.; ARF, O.; SÁ, M.E. Efeito da rotação de culturas e adubação verde sobre o rendimento do feijoeiro "de inverno" (Phaseolus vulgaris L.). In: REUNIÃO NACIONAL DE PESQUISA DE FEIJÃO, 6., Salvador, 1999. Anais. Goiânia: Embrapa Arroz e Feijão, 1999. p.649-651.

CASTRO, L.G.; LIBARDI, P.L.; JONG VAN LIER, Q. de. Soil water dynamics in a Brazilian infiltration terrace under different management practices. In: PAGLIAI, M.; JONES, R. (Org.). Sustainable land management. Environmental protection: a soil physical approach. 1.ed. Reiskirchen: ISSDS, 2002. v.35, p.191-198. (Advances in GeoEcology, 35).
COSTA, J.L.; BEDMAR, F.; DANIEL, P.E.; APARÍCIO, V.C. Nitrate and atrazine leaching from corn in the Argentinean Humid Pampas. In: INTERNATIONAL WORKSHOP ON GROUNDWATER RISK ASSESSMENT AT CONTAMINATED SITES AND INTEGRATED SOIL AND WATER PROTECTION, 2., Tübingen, 2003. Tübingen: Eberhard Karls Universität Tübingen, 2003. p.241-245.

EMPRESA BRASILEIRA DE PESQUISA AGROPECUÁRIA EMBRAPA. Centro Nacional de Pesquisa de Solos. Sistema brasileiro de classificação de solos. Rio de Janeiro: Embrapa Solos, 1999. 412p.

FANCELLI A.L.; DOURADO NETO, D. Produção de milho em terras baixas. In: FANCELLI, A.L.; DOURADO NETO, D. (Ed.). Milho: Tecnologia e produção. Piracicaba: ESALQ/USP/LVP, 2005. cap.3, p.21-33.

GAVA, G.J.C. Compartimentalização do nitrogênio no sistema soloplanta na implantação na implantação do semeadura direta no ciclo da cultura do milho. Piracicaba: USP/ESALQ, 2003. 125p. (Tese - Doutorado em Ciências).

GEE, S.W.; BAUDER, J.C. Particle size analysis. In: KLUTE, A. (Ed.). Methods of soil analysis. Part 1. Physical and mineralogical methods. Madison: ASA, 1986. p.383-412.

GINE, M.F.; BERGAMIN FILHO, H.; ZAGATO, E.A.G.; REIS, B.F. Simultaneous determination of nitrate and nitrite by flow injection analysis. Analytica Chimica Acta, v.114, p.191197, 1980.

GOLLANY, H.; MOLINA, J.A.; CLAPP, C.; ALLMARAS, R.; LAYESE, M.; BAKER, J.; CHENG, H. Nitrogen Leaching and denitrification in continuous corn as related to residue management and nitrogen fertilization. Environmental Management, 2006. Available in: <http://www.ars.usda.gov/ research/publications/publications.htm>. Accessed in: 15 jan.2005.

HALVORSON, A.D.; WIENHOLD, B.T.; BLACK, A.L. Tillage and nitrogen fertilization influence grain and soil nitrogen in a annual cropping system. Agronomy Journal, v.93, p.836-841, 2001.

HILLEL, D.A.; KRENTOS, V.K.; STILIANOV, Y. Procedure an test an internal drainage method for measuring soil hydraulic characteristics in situ. Soil Science, v.114, p.395-400, 1972.

HOEFT, R.G. Desafios para a obtenção de altas produtividades de milho e de soja nos EUA. Piracicaba: POTAFOS, 2003. p.1-4. (Informações Agronômicas, 104). 
KIEHL, E.J. Manual de edafologia. São Paulo: Agronômica Ceres, 1979. 262p.

KIEHL, J.C. Nitrogênio: Dinâmica e disponibilidade no solo. In: CURSO DE ATUALIZAÇÃO EM FERTILIDADE DO SOLO, Campinas, 1987. Campinas: Fundação Cargill, 1987. p.139157.

LIBARDI, P.L. Dinâmica da água no solo. 2.ed. São Paulo: Editora da Universidade de São Paulo, 2005. 329p.

LIBARDI, P.L.; REICHARDT, K. Destino da uréia aplicada a um solo tropical. Revista Brasileira de Ciência do Solo, v.2, p.40-44, 1978.

LIMA, V.E.; LIMA, J.M.J.C. Fundamentos da pedologia. Curitiba: UFPR, 2000.

MAGALHÃES, P.C.; DURÃES, F.O.M.; PAIVA, E. Fisiologia da planta de milho. Sete lagoas: EMBRAPA/CNPMS, 1995. 27p. (Circular Técnica, 20).

MARTINS, S.G.; SILVA, M.L.N.; CURI, N.; FERREIRA, M.M. Avaliação de atributos físicos de um Latossolo Vermelho distroférrico sob diferentes povoamentos florestais. Cerne, v.8, p.32-41, 2002.

MEIRELLES, N.M.F.; LIBARDI, P.L.; REICHARDT, K. Absorção e lixiviação de nitrogênio em cultura de feijão (Phaseolus vulgaris L.). Revista Brasileira de Ciência do Solo, v.4, p.83-88, 1980 .

RAIJ, B. van; CANTARELLA, H.; QUAGGIO, J.A.; FURLANI, A.M. Recomendações de adubação e calagem para o Estado de São Paulo. Campinas: Instituto Agronômico, 1997. 285 p. (Boletim Técnico, 100).

RASSE, D.P.; SMUCKER, A.J.M. Tillage effects on soil nitrogen and plant biomass in a corn-alfafa rotation. Journal of Environmental Quality, v.28, p.873-880, 1999.

REICHARDT, K.; LIBARDI, P.L.; MEIRELLES, N.M.F.; FERREYRA, H.F.F.; ZAGATTO, E.A.G.; MATSUI, E. Extração e análise de nitratos em solução do solo. Revista Brasileira de Ciência do Solo, v.1, p. 130-132, 1977.
SAINJU, U.M.; SINGHI, B.P. Tillage, cover crop and kill-planting date effects on corn yield and soil nitrogen. Agronomy Journal, v.93, p.878-886, 2001.

SAINZ ROZAS, H.R.; ECHEVERRIA, H.E.; BARBIERI, P.A. Nitrogen Balance as Affected by Application Time and Nitrogen Fertilizer Rate in Irrigated No-Tillage Maize. Agronomy Journal, v.96, p.1622-1631, 2004.

SHIPITALO, M.J.; EDWARDS, W.M. Seasonal patterns of water and chemical movement in tilled and no-till column lysimeters. Soil Science Society of America Journal, v.57, p.18-223, 1993.

SILVA, J.C.A. Movimento e perdas por lixiviação de nitrogênio $\mathrm{CO}\left({ }^{15} \mathrm{NH}_{2}\right)_{2}$ - em um Alfisol cultivado com milho (Zea mays,L.). Piracicaba: USP/ESALQ, 1982. 68p. (Dissertação - Mestrado em Solos e Nutrição de Plantas).

SOGBEDJI, J.M.; Van ES, H.M.; YANG, C.L. Nitrate leaching and nitrogen budget as affected by maize nitrogen rate and soil type. Journal of Environmental Quality, v.29, p.1813-1820, 2000 .

STARK, J.C.; JARREL, W.M.; LETEY, J. Evaluation of irrigationnitrogen management practices for celery using continuousvariable irrigation. Soil Science Society of America Journal, v.47, p.95-98, 1983.

TRIVELIN, P.C.O.; SALATI, E.; MATSUI, E. Preparo de amostras para análise de ${ }^{15} \mathrm{~N}$ por espectrometria de massas. Piracicaba: CENA/USP, 1973. 41p. (Boletim Técnico, 2).

WEED, D.A.J.; KANWAR, R.S. Nitrate and Water present and flowing from root-zone soil. Journal of Environmental Quality, v.25, p.709-719, 1996.

Received November 07, 2005

Accepted July 23, 2006 